\title{
CUSTOM, JOB REGULATION AND DOCK LABOUR IN LIVERPOOL, 1911-39*
}

It has been said that no other British industry, with the possible exception of coal mining, can claim such a rich or conflict-prone history of labour relations as the docks. ${ }^{1}$ In fact the major issues of more recent years in port transport concerning the nature of employment, strike activity and restrictive practices can only be fully understood within a historical perspective. The main focus of interest, however, of the plethora of public inquiries and research studies relating to the docks over many years has inevitably been the nature of employment - especially the effects and reforms of the casual system. ${ }^{2}$ Far less attention has been devoted to methods of job regulation and control over work as tools of analysis, now regarded as core elements in the study of industrial relations. ${ }^{3}$ In this respect one particularly significant, but largely neglected, area concerns the development of collective bargaining within the industry as the main regulatory mechanism, over its formative and consolidatory period broadly spanning the two world wars. ${ }^{4}$ By this time trade unions had been

* I am grateful to the Employers' Association of the Port of Liverpool for making their records for this period available to me, and to the Nuffield Foundation for financial support.

1 M. P. Jackson, Labour Relations on the Docks (London, 1973), p. 3.

2 In particular the Final Report of the Committee of Inquiry under the Rt. Hon. Lord Devlin into Certain Matters Concerning the Port Transport Industry [Cmnd 2734] (1965). For the Liverpool docks the main references are Report of the Commission of Inquiry Into the Subject of the Unemployed in the City of Liverpool (Liverpool, 1894); E. F. Rathbone, An Enquiry Into the Condition of Dock Labour at the Liverpool Docks (Liverpool, 1904); R. Williams, The First Year's Working of the Liverpool Docks Scheme (London, 1914); F. G. Hanham, Report of an Inquiry into Casual Labour in the Merseyside Area (Liverpool, 1930); The Social Survey of Merseyside, ed. by D. C. Jones (Liverpool, 1934).

3 See A. Flanders, Management and Unions: The Theory and Reform of Industrial Relations (London, 1970), p. 86; J. Purcell and R. Smith, The Control of Work (London, 1979), p. 4.

4 Two studies relating to the inter-war period, R. Charles, The Development of Industrial Relations in Britain, 1911-1939 (London, 1973), and H. F. Gospel, "Employers 
granted recognition by employers and machinery for joint determination of the terms and conditions of employment established on a comprehensive basis. It was the Port of Liverpool which took the lead in these innovations, since in 1911 it was the first to establish machinery for negotiation between ship-owners and employee representatives ${ }^{5}$ via the Dock Labour Joint Committee, and, as is well known, pioneered an attempt in the following year at the organization of dock labour throughout the port by means of a jointly controlled registration scheme. ${ }^{6} \mathrm{I}$ have dealt at length elsewhere with the movement, as it affected Liverpool, which took place in the inter-war years from local to national negotiations over wages and other substantive matters, thereby enlarging the scope of the bargaining unit. ${ }^{7}$ Yet throughout the period a significant degree of determination in labour matters remained with the local joint committee, which continued to adjust disputes and administer working arrangements.

The object of this paper is to examine for one important port the process of transformation of work regulation from initially one of custom, or sometimes imposition by one party, into negotiated and ultimately codified rules and agreements. Furthermore, in relation to the new institutional arrangements for collective bargaining it may be asked how did the joint committee function, how did it attempt to secure compliance with its decisions across the port, and what measure of success did it achieve in relation to its objectives?

As a means of regulating work standards as well as wage levels custom was the most important authority in British industrial relations throughout much of the nineteenth century. ${ }^{8}$ On the docks methods under which work was to be carried out, dependent upon factors such as the type of ship, cargo to be discharged and quayside facilities available, would emerge, and

Organizations: Their Growth and Function in the British System of Industrial Relations in the Period 1918-1939" (unpublished Ph.D. thesis, University of London, 1974), either omit port transport, or deal with it in only a cursory fashion, because access was not allowed to records and documents.

${ }^{5}$ Committee on Industry and Trade, 1924-27, Minutes of Evidence, Vol. II, p. 1048.

${ }^{6}$ See Williams, The Liverpool Docks Scheme, op. cit., p. 4.

${ }^{7}$ R. Bean, "The Port of Liverpool: Employers and Industrial Relations, 1919-39", in: Commerce, Industry and Transport, ed. by B. L. Anderson and P. J. M. Stoney (Liverpool, forthcoming in 1983). This essay also analyses the relationships between Liverpool port employers and other constituent employer groupings at national level.

${ }^{8}$ H. A. Clegg, The System of Industrial Relations in Great Britain (Oxford, 1970), p. 4; E. J. Hobsbawm, "Custom, Wages and Work-load in Nineteenth-century Industry", in Labouring Men (London, 1964), pp. 344-70. See also C. Behagg, "Custom, Class and Change: The Trade Societies in Birmingham", in: Social History, IV (1979), pp. 455-80. 
over the course of time these became firmly embedded in the absence of challenge, so that they acquired the status of "established practices" and "customary rules". ${ }^{9}$ Such rules were well understood despite their lack of formalization, or external sanction to enforce their upholding. ${ }^{10}$ In fact, their observance was dependent upon the sense of legitimacy engendered by their long-term and mutual, if implicit, acceptance. Thus, by precluding arbitrary action designed to change the status quo adherence to custom was a major means of regulation of conditions to be observed in the employment relationship. Certainly, although work practices and routines might be largely taken for granted, if an employer deviated markedly, or broke away completely, from custom, then his workforce would be expected to object since for them it served as a defence against demands for excessive labour effort, speed-up and overwork. In Liverpool even after the introduction of negotiated agreements via collective bargaining, for a limited section of the port in 1903 and more comprehensively in 1911, in both cases it was stipulated that "all matters not provided for in this agreement to be according to custom as existing prior to this agreement". ${ }^{11}$ There were even some instances in which custom remained predominant despite the terms of the agreement. For instance, when quay porters working timber cargoes in the South docks in the 1920's decided not to proceed during inclement weather, the forty-year-old custom of paying the men for hours actually worked continued, although employers were then entitled under the agreement to withhold pay for the full half-day engagement. ${ }^{12}$

Some customs, such as weighing cargo at the shipside upon discharge, appertained to the entire port, whereas others were confined to particular, geographic areas of the docks. The Port of Liverpool itself covered some

9 The same was true of dock work in other countries such as the United States. In the Port of New York, for instance, tradition, habit and established customs and practices also had a pervasive influence. See C. Barnes, The Longshoremen (New York, 1915), p.30, and V. H. Jensen, Strife on the Waterfront: The Port of New York Since 1945 (Ithaca, 1974), p. 142.

${ }^{10}$ For an analysis of the role of custom see M. Weber, Economy and Society (New York, 1968), I, pp. 29, 319-20, 332. He distinguishes "custom", in the sense of adherence to practices based upon long standing, from "convention", which relates to conduct which is sought to be induced. Thus, "regularities of conduct ('customs') can [...] become the source of rules for conduct ("conventions')" (p. 332) - although the borderline between the two is fluid.

11 Agreement Between Master Stevedores and Master Porters of Liverpool and the National Union of Dock Labourers, February 1903, Webb Trade Union Collection, Section C, Vol. 46, British Library of Political and Economic Science, London; Agreement as to Terms and Conditions of Dock Labour in the Port of Liverpool, August 1911 (the "White Book"), Cunard Papers, Booth files.

12 Dock Labour Joint Committee, Minutes (hereafter DLJC), 8 February 1921, Employers' Association of the Port of Liverpool. 
thirty-seven miles of quay space, handled every conceivable variety of cargo and could be regarded as comprising a number of partially specialized sections, each with its own methods of working and deployment of labour. Three broad divisions consisted of Birkenhead for loading and export cargoes, and, on the Liverpool side of the Mersey, the deep-water Northern docks accommodating the Atlantic liners together with the South docks for smaller steamers. In Birkenhead not only were there differences in hours of work and wage rates, but also in job conditions and employee work-load in relation to the customary weight and content of slings of cargo. On the Liverpool side also, methods of work and the manning of gangs on large passenger liners contrasted with those on smaller cargo ships because of the height of the vessel above the quay to which the slings had to be lifted, as well as the depth of the holds. ${ }^{13}$ Apart from such spatial and functional variations the multiplicity of separate employers of dock labour ${ }^{14}$ within a largely disorganized industry meant that there was, in addition, a bewildering conglomeration of individual arrangements regulating work organization such that each firm had its own, particular customs.

Such variation was partly a reflection of the diversity of trades served by the port, which required correspondingly different methods of handling particular commodities, as well as varied equipment for quay and shed accommodation. It was the policy of the port authority, the Mersey Docks and Harbour Board, to leave to the discretion of individual companies the provision of such extensive, or limited, facilities at their appropriated (leased) berths as they wished, with the result that in some cases the sheds lacked cargo-handling equipment of any kind and were entirely dependent upon manual labour. ${ }^{15}$ Furthermore, many of the older docks were not equipped with cranes, particularly those constructed with very narrow working space ("quay aprons") alongside the vessels. At these points cargo was loaded by ship's gear, hauling ("skidding") the sling-loads up inclined stages or planks and then lowering it into the holds by means of the winches. In the newer docks with ample quay working space, shore cranes were employed in direct lifts from the quay to the vessel's hold. The consequences for cargo handling were that the number of men to a gang and packages to a rope sling varied not only from dock to dock, but as

13 (Employers') Dock Labour Organization Committee, Minutes (hereafter DLOC), 20 November 1925.

14 In 1914 there were 246 employers of dock labourers in Liverpool. T. J. Marquis, Handbook of Employments in Liverpool (Liverpool, 1916), p. 61.

15 See Chamber of Shipping of the United Kingdom, Port Facilities of Great Britain (London, 1924), p. 160; E.P. Cotter, The Port of Liverpool (Washington, 1929), p. 38, 132. 
between steamers berthed in the same dock and sometimes even from hatch to hatch. ${ }^{16}$

In some instances work practices had come to be regulated and norms established not only by means of customary conventions which had grown up and become implicitly sanctified over the course of time, but, where they had the power, by the explicit and autonomous prescription of the dockers themselves. Some groups of dock workers were in a strong bargaining position because their jobs were specialized and relatively skilled requiring manual dexterity and knowledge of the most effective procedures - such as deal carriers, ricers, corn-trade bushellers and salt porters, or were exceptionally exacting as in the case of coalheavers. The early dock labourers' unions had therefore sought to model themselves upon the unions of skilled artisans, and on the Mersey where they secured recognition from small and unorganized employers, as along the South docks and later in Birkenhead, they enforced their own "working rules". ${ }^{17}$ In addition, the organization of production on the docks was centered upon the work group because the gang was the basic unit, thereby resulting in a high degree of autonomy amongst dockers at workplace level. ${ }^{18}$

By 1911 , at a time of reviving trade together with an upsurge in union activity and membership, ${ }^{19}$ those major shipping lines at the Northern docks which had hitherto successfully resisted union recognition felt obliged to reconsider their position. The main problem was that unpredictable and sectional work stoppages were then occurring with increased regularity throughout the port. All ship-owners were vulnerable to unanticipated stoppages by either seamen or dockers, particularly during a period of emerging prosperity, since time spent in port is unproductive. This was especially the case in a predominantly liner port such as Liverpool, where, in order to meet fixed sailing schedules and avoid the detention of a ship, owners were often prepared to incur higher labour

16 DLOC, 18 October 1923.

17 Employers alleged that there was little short of a reign of tyranny at the South docks and in Birkenhead through the union's being able to dictate its own terms and conditions to the masters. Similarly, the coalheavers' organization had enforced its own rules and regulations since the 1870s. Journal of Commerce, 22 February 1892 and 20 October 1893.

18 S. Hill, The Dockers: Class and Tradition in London (London, 1976), p. 68. See also D. F. Wilson, Dockers: The Impact of Industrial Change (London, 1972).

${ }^{19}$ G. S. Bain and R. Price, Profiles of Union Growth (Oxford, 1980), p. 70, show that between 1910 and 1911 union membership in Port and Inland Water Transport increased from 51,000 to 141,000 . 
costs in the interest of getting their vessels away. ${ }^{20}$ These circumstances obviously conferred great economic power upon dock workers, so that particular groups of them would take direct action by walking off the ship or quay in order to enforce their demands.

Employers were now searching for some means of reducing uncertainty in relation to the port's labour-force. They required more orderly arrangements which would regularize labour relations and contain the number of strikes by strengthening control and discipline of dock workers at the quayside. It was their belief that the frequent stoppages were damaging not only the competitive position of the port in general, but also the profitability of the larger, predominant shipping firms themselves. ${ }^{21}$ Some of the more forward-looking employers recognised the potential gains to be secured from pursuing a positive strategy in labour matters by developing relations with the dock labourers' union (NUDL), instead of continuing to refuse to acknowledge its existence. They had perceived the value of the union as a possible partner in the growing problem of labour regulation, control and discipline. At times of heightened business activity there was a need not only for fewer stoppages, but also for getting dock workers to end their "irregular" habits and offer themselves for work more steadily. ${ }^{22}$ The union could be instrumental to employers' objectives, since collaboration between the parties in the form of a new unity of employerunion authority might enable them to achieve with the union, working through its leaders, what they could no longer achieve by themselves. ${ }^{23}$

Having resolved in the wake of the strikes that henceforth they would take united action on all questions concerning the employment of labour, ${ }^{24}$

20 Journal of Commerce, 13 July 1911.

${ }^{21}$ R. Bean, "Employers' Associations in the Port of Liverpool, 1890-1914", in: International Review of Social History, XXI (1976), p. 376.

22 DLJC, 29 October 1912.

${ }^{23}$ Compare A. Fox, Beyond Contract: Work, Power and Trust Relations (London, 1974), p. 251: "the employer was subject to such a succession of minor disputes and stoppages that he was ready to recognize a union if in return it was willing and able to control his employees and process their grievances in an orderly manner with the minimum of disruption". A. Flanders, "The Tradition of Voluntarism", in: British Journal of Industrial Relations, XII (1974), pp. 355-56, has also emphasized employer interest in bringing about union recognition in order to secure union assistance in managerial control, in making and upholding rules, for the sake of gaining employee consent and co-operation and avoiding costly strikes.

${ }^{24}$ Co-ordinated employer action in labour matters was facilitated because of the increased concentration amongst employers which had taken place, such that the port transport industry on the Mersey had come to be dominated by a limited number of big shipping firms. See Hobsbawm, Labouring Men, op. cit., p. 213. In this respect it has been pointed out that in oligopolistic-type industries "the relatively small number of largescale employers [...] facilitates collective organisation and the small employers are 
ship-owners met the union leaders in conference and negotiated a formal agreement. Union hours and wage scales for particular classes of cargo were to appertain throughout the port amongst the signatory firms, but not manning levels or content of slings, since the previously non-union firms at the North end would not comply. It was also agreed no longer to discriminate in favour of non-union labour at the stands, although employers were not prepared at this stage to grant an unequivocal union preference in hiring. The union thus achieved major gains, since it had been legitimized by port-wide recognition, its status enhanced and its security as a bargaining agent more firmly established. In return, it was to help ensure that work was carried out efficiently and undertook specifically not to interfere with the method of working cargo on ship or quay, subject to a limited right of appeal. ${ }^{25}$ Employers wished to retain the maximum degree of control at enterprise level so as to prevent escalating costs, and were therefore unwilling to permit union-imposed incursions into existing arrangements of work method and labour utilization. Thus union involvement in decision making was to take place within strictly defined parameters.

A permanent joint committee was appointed for future bargaining on substantive issues, to negotiate revisions in wage rates and hours - before the introduction of national wage-rate setting for the industry in 1920 . In view of the importance attached to procedure in the evolution of British industrial relations it would also function as a disputes-settlement mechanism to bring about the orderly adjudication of grievances without recourse to work stoppages, which were not to take place pending the committee's decision. By establishing a forum for regular communication between the parties the committee would act as a monitoring device for the reference and adjustment of disputes concerning the interpretation, or alleged infringement, of the agreement. It was also given authority to mediate on conditions of employment for any particular class of work the manning of gangs and method of working - where it was alleged that these were having a deleterious effect upon the health and safety of the men. In one referred dispute for instance, at the Harrison shipping line, the men had refused to discharge the requisite number of bags of flour to a sling on the grounds that the job was thereby "hastened", a bigger "lift" was entailed and they had insufficient breathing space between lifts. ${ }^{26}$

constrained to join through the economic impossibility of their taking independent action against the unions". G. K. Ingham, Strikes and Industrial Conflict (London, 1974), p. 42. ${ }^{25}$ Agreement as to Terms and Conditions of Dock Labour in the Port of Liverpool, 1911. ${ }^{26}$ DLJC, 20 January 1919. There were also health hazards from discharging particular commodities, such as dust in grain handling and the pungent and acrid atmosphere when shovelling phosphate rock. In some disputed cases the view of the Port Medical Officer of Health was sought. 
Dock labour was also a notoriously hazardous occupation in its own right, ${ }^{27}$ as well as being subject to the possibility of employer-induced undermanning in the interests of economy, or a faster pace of work to get a quick turn-around so as to meet the sailing schedule. With this one exception, however, the committee had no power to interfere with an individual employer's method of working so long as the firm could prove "custom" in its support. In those instances where the committee did give rulings, then, because it consisted of an equal number of representatives of both parties (with the employers' side providing the chairman), the union became associated with the decisions reached and was fully committed to upholding them. The union officials were expected "to control their constituents by enforcing decisions of the committee [...] and strict adherence to the terms of the agreement". ${ }^{28}$

Port-wide collective bargaining was therefore established on the employers' initiative and over the next decade it continued to develop very much upon their terms. They believed that the new arrangements with their emphasis upon procedural principles would afford an institutional constraint upon the use of industrial power, and thereby have the effect of "checking any spasmodic outburst of disaffection which may take place". ${ }^{29}$ It was anticipated that the development of procedural norms for the regulation of industrial relations would be associated with a reduction in strike activity, because such norms become an alternative means of resolving conflict ${ }^{30}$ In fact, in the early years of its existence the committee was primarily concerned with adjusting numerous small disputes relating to the interpretation of the agreement - typically concerning the nature and classification of particular commodities attracting enhanced payment - , which otherwise would undoubtedly have resulted in many more work stoppages. In cases of alleged breach of the agreement by individual firms the union would refer these to the committee when they could not be settled directly. Similarly, employers would bring complaints of unauthorized action or sectional wage demands to the union's attention in order to secure the honouring of agreements. On some occasions where the

27 Dock employment was dangerous since it involved working from heights, over poor flooring and in bad lighting. In 1927, for example, the factory inspectorate found that in the Port of Liverpool there were 925 dock accidents, 20 of them fatal. DLJC, 25 February 1931.

28 Ibid., 23 December 1912. The union representatives included a number of working dockers as well as officials. In practice, an exact equality of numbers from each side of the committee was unimportant, since decision taking by vote was regarded as being unlikely. Ibid., 19 November 1922.

29 Liverpool Daily Post and Mercury, 22 August 1911.

30 Cf. Ingham, Strikes and Industrial Conflict, op. cit., p. 35. 
union appeared unable to secure compliance with the terms of the agreement the employers invoked the sanction of suspending meetings of the joint committee and processing no business for several weeks until a satisfactory outcome had been secured. ${ }^{31}$ At other times they would threaten to terminate the entire agreement, which would have involved withdrawal of recognition from the union. ${ }^{32}$

Therefore, there remained large elements of "distributive" bargaining ${ }^{33}$ (an adversarial process) in the committee's deliberations on contentious issues. Yet the emphasis centered, wherever possible, upon problem-solving and integrative potential directed particularly towards the resolution of conflict, in which both parties had a common interest. ${ }^{34}$ Inevitably such a close working relationship was regarded with suspicion by many of the union's rank and file, primarily because they had a different "utility function" from that of their leaders. The leadership was especially concerned with the survival and growth of the union organization itself, so that in temporarily propitious economic circumstances it might refrain from pressing demands upon employers to the limits of its bargaining power in the interests of their long-term relationship. In contrast, the membership - with a shorter time horizon and more concerned with immediate, employment-related issues - were more ready to exploit any short-term bargaining advantage. ${ }^{35}$

These intra-organizational problems between the union and its members became pronounced during 1912 in relation to the setting up of a clearing-house scheme for the greater regularization of casual dock labour in the port. In order to begin to eliminate the large, overall surplus which existed $^{36}$ and correct the imbalance between daily shortage and excess of labour in various sections of the port, it was necessary to confine employment to regular dock workers by providing them with an identification

31 DLJC, 23 December 1912, 26 May 1913 and 18 March 1924.

32 Ibid., 15 July 1912 and 10 December 1919.

${ }^{33}$ R. E. Walton and R. B. McKersie, A Behavioral Theory of Labor Negotiations (New York, 1965), p. 4. They distinguish between "distributive" bargaining (a fixed-sum game) to resolve pure conflicts of in terest, and "in tegrative" bargaining (a varying-sum game) to find common or complementary in terests and resolve problems confronting both parties. ${ }^{34}$ Employers wanted fewer disputes in order to help maintain and expand the trade of the port, whilst the union had been both embarrassed and less effective on occasions because of unofficial action by its members - as in the general transport strike of August 1911 in Liverpool. Thus both stood to gain from greater centralized control of the dock labour-force.

${ }^{35} \mathrm{Cf}$. Walton and McKersie, A Behavioral Theory of Labor Negotiations, op. cit., p. 290. ${ }^{36}$ R. Williams, The Liverpool Docks Problem (Liverpool 1912), p. 11, shows that there was a surplus of at least 7,000 men over and above the requirements of the port at its busiest season. 
tally and to encourage mobility as between employers. Thereafter the joint committee would distribute at intervals, or withhold, issues of new tallies in accordance with the labour requirements of the port. Although the new system had been drawn up by the ship-owners in conjunction with union officials, the rank and file complained that they had been given no opportunity either to endorse or reject the scheme. Sexton, the union's secretary, even instituted proceedings for criminal libel against the authors of a pamphlet circulating at the docks intimating that he had conspired "to hand over the union to the employers to manipulate as they will". ${ }^{37}$ Some dock workers, emphasizing the oppositional element in the employment relationship, expressed a general unease that the new system must be to the employers' advantage in view of the resources which had been invested in its establishment and the insistence on its implementation. Others feared the loss of independence which the scheme was felt to entail in promoting more organized and regular work, particularly if it meant being obliged to do unfamiliar work for a different employer. Or, it was believed that within the context of a chronic excess supply of labour many workers, especially older ones, would gradually be squeezed out of the industry. ${ }^{38}$ In the event, when the scheme came into operation, Liverpool dockers struck against it for several days and in Birkenhead, with a long tradition of sectoral independence, the men held out for a month until they were defeated by the employers' importation of more than a thousand "free" labourers.

\section{III}

From the employers' standpoint the main purpose of the Dock Labour Joint Committee in the pre-1914 period had been to help keep the port free from stoppages so as to take full advantage of the improved trading conditions. After the war they were to place additional emphasis upon efficiency considerations and the securing of cost reductions within an increasingly competitive economic environment. In the inter-war years Liverpool began to lose trade steadily to other United Kingdom ports. ${ }^{39}$ In

37 Liverpool Daily Post and Mercury, 12 July 1912.

38 Ibid., 16 and 27 July, and Report of the Court of Inquiry Concerning Transport Workers, Wages and Conditions Of Dock Labour [Parliamentary Papers, 1920, XXIV], p. 296. In Birkenhead it was claimed that some dockers preferred what was termed the "jubilee system" of employment, working for only two days and one night to provide sufficient money for a week. Birkenhead News, 17 July.

${ }^{39}$ G. C. Allen et al., The Import Trade of the Port of Liverpool (Liverpool, 1946), p. 23, shows that during the period 1924-38 Liverpool was gradually losing ground relative to other ports and that, superimposed on this trend, there was a strong cyclical influence tending to make Liverpool's share lower in the years of depression. 
view of the relatively high costs of cargo handling in the port ${ }^{40}$ the employers, as part of their response, launched an offensive against continued adherence to certain customs which were felt to be impeding the efficiency of work organization. By definition custom and established practices were rooted in the past, and although setting regulative standards and providing a defence against labour-force challenge, the dictates of custom could, nevertheless, prove a serious obstacle in the face of changing needs and conditions. Employers now wished to be freed from the constraints of particular customs to work along lines which they considered most efficient and economical. They asserted that they "could not be guided by past practice where it was found that it simply led to expensive and entirely unnecessary methods of working [...], and that such methods would have to be abolished". ${ }^{11}$

However, there would clearly be problems in attempting to eradicate customs of many years standing, not least because of the diversity and disparity of practice in different parts of the dock estate, as well as amongst individual firms therein. Moreover, as Clegg has pointed out, although not inviolate for all time, their having arisen without specific prescription meant that there was no prescriptive way of actually changing a custom. ${ }^{42}$ On the Liverpool docks there could be disagreement about both the origin of a particular custom and its current purpose. When, for instance, an employer in the Rangoon rice trade wished to end the longstanding practice of giving an unscheduled, additional payment - "ripo" or beer money - to porters unloading the cargo, since the rice no longer arrived in a dirty and dusty condition, it was discovered that other firms based the same payment on output in terms of number of bags discharged per day. ${ }^{43}$ It would therefore appear that within the segmented labour market of the docks the same custom might be used for different purposes amongst various firms, in this case either as a type of "condition" money or as an informal piece rate.

As a start to displacing the primacy of custom under post-war conditions, coincident with the commencement of changing techniques of handling cargo via the growing mechanization of the port - as will be shown -, in 1919 the employers secured a significant amendment to the agreement. Whilst reiterating that no union interference was to take place with the

40 Board of Trade, An Industrial Survey of Merseyside (London, 1932), p. 84.

41 DLJC, 29 September 1920.

42 H. A. Clegg, The Changing System of Industrial Relations in Great Britain (Oxford, 1979), p. 2.

${ }^{43}$ DLJC, 8 April and 5 December 1924. Also, by longtime local custom at the South docks a similar extra payment was made to porters handling locust beans. 
method of working, there was now added: "whether in accordance with previous custom or not, nor oppose the use of mechanical appliances". ${ }^{44}$ This modification was intended to give employers an unambiguous, discretionary power to alter work methods, in return for which they agreed not to employ non-union labour when union labour was available. Over the next two years employers made proposals to further adjust local working agreements in order to remove what they regarded as certain malpractices by the men, and to reduce high overtime payments and "plus" rates for some specialized cargoes. However, the union (now TGWU) refused to co-operate and put forward instead its own set of "port working rules" for employer approval, reflecting prevailing arrangements amongst those firms which had worked under union conditions before 1911. The dilemma for the employers was that a negative response, refusing to negotiate and attempting to enforce the union non-interference clause of the agreement, might succeed in preventing cost escalation for the time being. But it might also lead to serious sectional trouble and to a less satisfactory, ultimate outcome through piecemeal imposition of its rules by the union. ${ }^{45}$ It was therefore decided to adopt a positive stance and negotiate an agreed code of jointly determined rules in order to attempt to secure an outcome closer to their own preferred position, with the proviso that the rules were not to lead to any general increase in the costs of working the port.

The process of consolidating, unifying and thereby re-defining diverse customs into formally agreed rules was based upon adopting as a standard what was done by the majority of individual firms throughout the port, rather than the practices prevalent in any particular area of the docks. Thus, in framing the rule custom was designated as being related to the specific employer rather than to the locality. ${ }^{46}$ Once the rules had been agreed they would then take precedence over custom - both sides were specifically committed to upholding them, whereas their obligation to custom had been less explicitly clear-cut. ${ }^{47}$ Indeed, the applicability, or even the existence of custom might be disputed in particular instances in the absence of an unambiguous source of authority. In the case of those cargoes and operations for which no specific provision was made in the rules these were to continue to be worked in accordance with the estab-

44 Ibid., 22 March 1919.

45 Employers' Association of the Port of Liverpool, Committee Minutes, 11 July 1924.

46 DLJC, 28 August and 8 October 1925.

47 Cf. Clegg, The Changing System of Industrial Relations, op. cit., p. 27. 
lished practice of the particular employer, or the decision of the committee. It therefore became possible for the committee now to override individual custom, even in the absence of a specific rule. One firm of contracting stevedores which could be shown persistently to overload slings and underman gangs was told to follow the general custom of the port, and if it felt some modification was necessary it could formally raise the matter for discussion. ${ }^{48}$

The decision to establish the rules upon port-wide majority practice, although no doubt facilitating agreement at the time, was to cause considerable problems during the 1930's in the specialized and more self-contained section of the port at Birkenhead. The precipitating cause was an attempt by certain employers to put excessive weight in the slings, speeding up the throughput in order to help reduce costs. ${ }^{49}$ Frequent stoppages were now taking place, since the men responded by refusing to load slings even of the weight permitted by rule or custom. They disputed the application of certain rules for particular commodities, because it was claimed that maximum loads of $12 \mathrm{cwt}$ per sling, when consisting of a large number of small packages typical of much of the high-grade cargo on that side of the river, made unreasonable demands on the men working in the holds. Where the local union delegates wanted the slings to be regulated by the more favourable custom of an individual firm, they would claim that the relevant rule did not apply because the packages concerned were "boxes", rather than "cases" as specified in the rules. Yet for other commodities they might interpret the rules in a more elastic manner by extending or "straining" them to encompass items which were clearly not intended to be covered at all, such as including drums (for which there was no rule) as well as cases and bales within the maximum permitted sling weights. Conversely, they would sometimes insist on a literal interpretation and strict compliance with the rules, refusing to load sling cargoes containing a few pounds more than the permitted maximum..$^{50}$

Thus the dockers felt that rules based on majority employer practice throughout the entire port were wrong when applied to a relatively small section like Birkenhead,and they continued to dispute the applicability of the rules in particular cases by probing their boundaries and ambiguities. ${ }^{51}$ They also objected to the lack of uniformity of practice within such a confined area of the port for those commodities which were not covered by

48 DLJC, 26 October 1932 and 2 May 1933.

49 Ibid., 1 September 1933.

50 Ibid., 20 December 1933, 31 May and 25 July 1934.

51 Compare J. Kuhn, "The Grievance Process", in: Frontiers of Collective Bargaining, ed. by J. T. Dunlop and N. W. Chamberlain (New York, 1967), p. 255. 
the rules, in that in Birkenhead there was a marked disparity as between firms in the permissible weight of slings for similar cargoes, with each employer claiming the right of custom. ${ }^{52}$ The eventual solution to these complaints, which were in effect a plea for separate treatment, was for the employers to arrive at an "understanding" with the union in the interests of greater harmony on the docks, at a time of improving trade and employment. Without either varying the terms of the port's working rules or prejudicing operations on the Liverpool side some informal adjustment could be made to the weight of sling loads on specific cargoes when applying and interpreting the rules in Birkenhead. Additionally, there would be greater standardization of custom for regulating other commodities, on the basis of majority practice as confined to that particular section of the port. ${ }^{53}$

\section{IV}

As well as regulating working conditions on existing freights and operations by means of negotiated rule or custom, it was also desirable to be able to discharge new cargoes and accommodate innovations in work methods with a minimum of industrial conflict. In fact, during the interwar period there came to be increasing use throughout the port of mechanical handling devices such as travelling cranes and overhead gantries, pneumatic suckers for bulk grain, electric bogies, together with piling and elevator stowing machines. ${ }^{54}$ The intention was to enable the discharge of vessels and clearance of goods from the quay at reduced cost in an industry in which labour represented about sixty per cent of the cost of loading and discharging, ${ }^{55}$ and where, in the immediate post-war years, wages were increasing at a more than average rate. ${ }^{56}$ In the case of the pneumatic (or suction) elevator, for instance, its advantages were not only that it was a more adaptable piece of apparatus, but also that it required no

52 DLJC, 24 April 1934.

53 Ibid., 3 December.

54 See Hanham, Casual Labour, in the Merseyside Area, op. cit., p. 45. Hydraulic coaling appliances were also installed in some parts of the port.

${ }_{55}$ Royal Commission on Transport, Minutes of Evidence, Vol. III (1930), q. 12, 652. This was the proportion in the ports of London and Liverpool.

56 Committee on Industry and Trade, Survey of Industrial Relations (1926), p. 86, indicates that between 1914 and 1925 wage increases for dock labour were substantially above the general average for a group of 13 export-related industries. See also F. Zimmer, "Portable Loading and Unloading Devices for Cargo Handling", in: Dock and Harbour Authority, I (1920-21), p. 18: "The rise in the cost of manual labour automatically promotes not only the perfecting of mechanical handling devices but also their more universal adoption." 
manual feeding, unlike the existing bucket (endless-belt) elevator, ${ }^{57}$ which was less mobile and needed a large amount of auxiliary, manual labour in shovelling or "ploughing" the grain towards the uptake, together with winch-end men on the ship's deck. At Liverpool it was calculated that a pneumatic elevator could discharge 1,500 tons of cargo per hatch in an eight-hour day, as compared with only 700 tons for a bucket elevator. ${ }^{58}$

Serious attention had been directed towards mechanical means of handling during the war years by the Elder Dempster company, whose steamers were principally concerned with the import of large quantities of fats and oils from West Africa (palm-oil kernels, ground nuts, etc.) for sustaining the war effort. In view of the shortage of labour on the docks at that time, together with widespread congestion on the quayside, the introduction of mechanical equipment was seen as a way of securing more rapid discharge, keeping the quay space clear and thereby promoting a faster turn-around of ships. Thus, after providing a power supply at its own expense, the company had introduced by 1916 some 30 portable electric cranes for the discharge of their cargoes together with a number of electric tractors for transporting timber logs. ${ }^{59}$ This firm was, however, very much of an exception, since by 1920 it could be claimed that in relation to mechanical devices (with the exception of certain specialist cargoes such as grain) "no whole hearted effort has been made to use them on a large scale in this country". ${ }^{60}$ In this respect two problems were identified: the fact that bulk goods such as grain could show demonstrably greater economies from their use than could "mixed" cargoes consisting of separate and individual packages, which did not lend themselves as readily to mechanical handling, and secondly labour-force hostility towards their

${ }^{57}$ In addition to bucket elevators for hoisting or vertical transmission, for conveying grain horizontally an engineer with the Mersey Docks and Harbour Board had first invented in 1868, for use in the Liverpool docks, a belt-conveyor together with a "tripper" or throw-off carriage for discharging the load at right angles to the belt. He had originally tried moving grain by means of a "worm screw", but found that its capacity was too low and power consumption too high. For simplicity of construction and economy of cost a rubber-and-canvas belt was most suitable. P. W. Britton, "The Transport, Storage and Manipulation of Grain", in: Institute of Civil Engineering, Minutes of Proceedings, CXXVI (1895-96), pp. 353-56; G. F. Zimmer, The Mechanical Handling and Storing of Materials (London, 1932), I, pp. 26, 43.

58 B. Cunningham, Cargo Handling at Ports, 2nd ed. (London, 1926), pp. 132, 151; R. E. Knight, "Discharge of Grain Cargoes in the Port of London by Pneumatic Elevator", in: Dock and Harbour Authority, II (1921-22), pp. 147-50.

59 G. H. Rae, "Mechanical Cargo Handling", in: Transactions of the Liverpool Engineering Society, XLIII (1922), p. 93-94. This paper contains detailed comparative-cost calculations for quay clearing by means of electric crane, as against trucking and piling bags by hand labour.

60 Zimmer, "Portable Loading and Unloading Devices", loc. cit., p. 18. 
utilization. It was clearly for the industrial-relations machinery to attempt to obviate the latter difficulty.

In order to facilitate the introduction of improved methods of handling goods on the Liverpool docks there was a requirement that where agreement could not be reached for new cargoes or operations not included in the rules the matter would be referred to the joint committee. ${ }^{61}$ There can be little doubt that this provision did smooth the introduction of technical change into the port by enabling its full implications to be discussed at an early stage. In effect, there could be no unilateral and arbitrary imposition of new methods by employers against union opposition. Instead, the pace and transition of change would be negotiated and subject to agreement. In the case of a stevedoring firm faced with a strike by employees discharging sugar because of its installation on the quay of electric piling machines hitherto used only in the warehouses, the company acknowledged that prior consultation should have taken place through the joint committee. It therefore withdrew the use of the machines in the interim, pending agreement on manning scales and rates of pay. ${ }^{62}$ At the Elder Dempster berths, where the installation of new handling devices continued to be developed, including electric trucks equipped with barrel-lifting gear and winnowing machines for recovering bag spillages, the committee agreed in principle to a fifty-percent reduction in the number of stowers per gang when using elevating and stacking appliances. But because of strong workforce opposition to further displacement of labour during a period of economic depression it was decided, on union advice, to retain the existing manning ratios for the time being in the interests of not retarding progress or the acceptance of machinery. ${ }^{63}$

Thus, although delay might be occasioned in the full utilization of new equipment by the need to secure agreement, once the decision had been made it could then more easily be implemented because the union had become a party to it. This was the case with the introduction of patent hand-grabs in place of ordinary cargo hooks, whose use on all bag and bale cargoes was sanctioned by the committee after the men had declined to use them for many months. ${ }^{64}$ Also, in the mid 1930's it proved possible to reach

61 DLJC, 10 October 1932.

62 Ibid., 7 February 1934.

63 Ibid., 12 June 1930. As an illustration of the extent of labour saving in the firm's dock sheds it was estimated that to secure the equivalent output from 5 electric trucks each operated by one man it would be necessary to employ at least 26 dock labourers. Dock and Harbour Authority, VIII (1927-28), p. 366.

64 DLJC, 11 August 1926. These devices also had the advantage of minimizing damage to the cargo. 
agreement on the contentious new practice of directly discharging cargoes such as bales of paper onto motor vehicles instead of first landing them on the quay, thereby reducing the size of gangs. It was accepted that Liverpool could not afford to be placed at a serious competitive disadvantage in relation to other ports and that employers had to be able to offer direct delivery, as required. ${ }^{65}$

It has been shown that in Liverpool recognition of the dockers' union was granted by employers in 1911 largely in the belief that industrial conflict could be contained and regularized by the development of collective-bargaining arrangements. The intention was to establish order, not in the sense of industrial peace completely undisturbed by conflict, but essentially of more regular, patterned and predictable behaviour. ${ }^{66}$ To this end institutional machinery was established at local level in the form of a joint body to interpret and uphold the authority of the agreement. There were to be further innovations in the procedural machinery by the setting up of various specialist sub-committees, including an emergency disputes committee empowered to investigate and give an immediate decision in sudden cases of dispute, without waiting for the monthly meeting of the full committee. Employers were, however, later to complain about the efficacy of this procedure in relation to disputes concerning enhanced rates of pay for allegedly abnormal working conditions. They maintained that the procedure was being misused by union delegates who would call for inspections as a way of establishing higher rates for particular commodities on a piecemeal or fragmented basis, circumventing formal application and full consideration by the committee. ${ }^{67}$

Employers were also well aware that if they wished the union to be in a position to control its members and deliver a disciplined workforce, then to retain credibility as a representative body its organizational strength had to be preserved. The fact was, however, that during the 1920's the union had been faced with a serious loss of subscribing membership. ${ }^{68}$ Consequently, although they continued to oppose the principle of compulsory union membership and were determined not to allow the docks to become "a

65 Ibid., 24 April 1933; DLOC, 9 May 1936.

66 Cf. J. F. B. Goodman et al., Rule Making and Industrial Peace (London, 1977), p. 16. 67 DLOC, 10 July 1939.

68 Employers' Association of the Port of Liverpool, Committee Minutes, 12 October 1923. It was estimated that of the 15,000 men working fairly regularly at the docks only between 10,000 and 12,000 were paying subscriptions, even though probably they had all once been in good standing. 
closed preserve for the present dockers and their sons", 69 employers were prepared to accede to the union's request for a re-registration of tallyholders as a means of restoring its membership. Re-registration would serve as a membership sanction for the union in that pressure could be put on men to rejoin because applications required endorsement by the union or employer, and preferably by both. ${ }^{70}$

The tally itself had originally been regarded by employers as a useful disciplinary device for dock labour, since it could be withdrawn from men who persistently refused to obey the decisions of the joint committee. Employers urged the union to impress upon its members that the possession of a tally carried with it an obligation to conform to the agreement, and that it could be recognized only for as long as that obligation was fulfilled. ${ }^{71}$ Yet, in the event, this disciplinary measure proved to be more apparent than real. Throughout the period under review the joint committee never exercized its power to withdraw tallies for breach of the agreement, since the union representatives were reluctant to deprive an offender of his means of livelihood and feared that to take such action would be to invite trouble throughout the docks. ${ }^{72}$

In fact, employers found that the collective agreement together with the joint-committee procedure was not as strong an instrument of control as originally had been envisaged. They seemed too ready to view the union as the equivalent of a hierarchical business organization handing down directives to a membership who were its "clients". ${ }^{73}$ This was seriously to underestimate the high degree of autonomy which various sectional groupings of dock workers could on occasion display in support of particularistic interests. A foremost example was the abuse of the breaks, or "spells", granted by employers to men unloading chilled or frozen meat from the refrigerated holds of ships. As early as 1911 an attempt had been made to control the prevalent, yet unauthorized, extension of spelling by writing into the agreement that where necessary spells might be granted as a privilege, but could not be demanded as a right. They were not to exceed a half hour and no more than two men in the gang would be granted spells at the same time. ${ }^{74}$ Yet it was found that organized and workgroup-en-

69 DLJC, 15 November 1923. Many tallies had been issued to dockers' sons.

70 Employers' Association of the Port of Liverpool, Committee Minutes, 18 November 1923.

71 Ibid., 11 September 1934. Employers complained that the union was allowing the men to get into a frame of mind whereby they felt that they had only to stop work to secure their demands.

72 DLJC, 30 June 1930.

73 Ibid., 24 February 1925.

74 Ibid., 28 November 1911. 
forced, systematic spelling could not be eradicated, even though the union did not officially countenance it and employers regarded it as always open to possible retrieval, if and when the opportunity arose. The "hour on hour off" system came to assume serious proportions in terms of the resultant high cost of discharging meat because of the need for greater overtime and weekend work, and it was subsequently extended to general cargoes as well. ${ }^{75}$ Nevertheless, although there were restrictions on output and working conditions could have been more economical, employers were largely satisfied since they maintained that Liverpool's position inirelation to output and costs compared favourably with other ports by the late 1930's. ${ }^{76}$

This paper has also investigated for one major port the under-researched topic of the role of custom as a means of work regulation. It has been shown how custom was replaced, or at least relegated to a subsidiary function, by the negotiation of formally agreed rules, which then became the dominant mode of job regulation during a period in which the port needed to begin to adapt to new and changed methods of working. Moreover, the evidence presented substantiates the view of Flanders that any discussion of the growth of collective bargaining itself is inadequate if it sees it only as a method of trade unionism and overlooks in its development the crucial part played by employers. ${ }^{77}$

75 Ibid., 10 October 1932. "Welting" on the Liverpool docks, whereby only half the gang worked at any given time, was more recently noted by the Devlin Committee of Inquiry (1965), p. 16.

76 DLOC, 18 June 1937.

77 A. Flanders, "Collective Bargaining: A Theoretical Analysis", in: British Journal of Industrial Relations, VI (1968), p. 3. 